Encrucijada/Crossroads: An Online Academic Journal

Issue 1, Volume 12003

\title{
Irene Vilar: Critique of Self-Sacrifice in the Puerto Rican Nationalist Party From the Forbidden Side of the Border
}

\author{
Melanie A. Pérez Ortiz \\ Departamento de Estudios Hispánicos \\ University of Puerto Rico
}

"Quizá debamos llegar a la conclusión de que la cohesión del movimiento nacionalista en sus años de mayor actividad se basaba, más en una condición psicológica común a sus miembros - el impulso suicida del puertorriqueño llevado a su más alta exacerbación-que en una doctrina revolucionaria o en una metodología terrorista". (163)

René Marqués, El puertorriqueño dócil (1965)

\section{Waiting at the Gate}

What has been called globalization is an economic, political, and cultural phenomenon that has provoked a lot of thinking by cultural theoreticians. This is because the manner in which meaning is produced either by communities or nations must change along with this reshaping of world relations that implies the always violent movement of people, industries and goods across borders. ${ }^{1}$ Just how and how much the production of meaning has, and will change is the question that academics are attempting to answer.

In this context, I am usually impelled to remember that Puerto Ricans, as well as Mexicans, have been crossing borders long before we started talking about globalization. ${ }^{2}$ For these communities migration was, in part, a product of the economic practices of the 1940s in their mother countries. In those years the industrializations that where called the Mexican Miracle and Operation Bootstrap where created, and with these programs access was given to a larger sector of the respective populations to modern spaces and consuming habits, in a manner similar to what is now called globalization.

Migration happened in this context because these projects needed to expel from the local territories the large populations of unemployed workers that challenged the possible success of the modernizing projects. Also because poor communities saw a relocation to the United States as a possibility of employment and social advancement that they did not think possible in their contexts of origin. 
In both these countries industrialization was negotiated with the United States, and in that sense, what is being called globalization now, can be understood as another stage of this same process of negotiating access to consuming markets with the Metropolis. In fact, the manner in which industrialization was achieved in both these countries can be defined with the same words that a Mexican scholar uses to describe globalization. According to him this phenomenon is the "globalization of the subordination to the more powerful countries (especially the United States), and to their representation matrixes" (Valenzuela 217). ${ }^{3}$ In this context, thinking about border crossing must be done by the incorporation of the scholarship that the Puerto Rican and Chicano communities have generated in the US. ${ }^{4}$

Migration was once identified with living in the ghetto, being rejected by both the community of origin and the new community in which the migrant was inserting her/himself. It was also identified with insecurity, lack of identity, and lack of being, which was translated as the lack of a voice, as many essays on cultural identity written in the 1940s and 50s suggest. ${ }^{5}$ The always growing scholarship on these communities suggests that the migrant subject in the US is not so confused and lacking as it was taught by main stream scholars. ${ }^{6}$ In this, and the context of globalization, migration is represented sometimes as the pleasure of being a "border subject," always able to cross frontiers and, simultaneously, interact with different and opposing realities. ${ }^{7}$ But, is the reality of migrations as pleasant as it is sometimes represented? I will attempt to offer an answer to this question by analyzing representations of migration in the Puerto Rican cultural field. I will read these representations in works written in two moments of this migration: the migration that was a product of the industrialization process in the island and the later one that is an indirect product of the same process and was called in Puerto Rican media as the "brain drain" from the island ("fuga de cerebros"), since it is the migration of professionals, or sons and daughters of professionals, looking for better job opportunities on the mainland. Irene Vilar's The Ladies' Gallery (1996) is a book that talks about a recent act of migration, in opposition, to Down These Mean Streets (1967), in which Piri Thomas describes the earlier migration of the working class sectors that industrialization displaced. In an old fashioned way, let's talk about the lady first.

\section{Boarding}

In 1996 an autobiography - that is also a memoir and a chronicle-was published for the first time in English translation. To my knowledge, this written text never saw the light in the Spanish language spoken by its author, Irene Vilar. It is the story of three generations of Puerto Rican women that includes Vilar herself, her mother, and her grandmother. A Message from God in the Atomic 
Age (Pantheon) was the first title that this book assumed, taken from a manifesto that the oldest of these three women had written in prison, where she was for having committed a political crime. In 1998 Vilar's book was re-edited by Vintage with a new title that made it more attractive to the possible (paperback) reader: The Ladies Gallery.

Personally, I find this second title more attractive for the many implications that can be read in it. It makes the book like a museum in which the ladies will be finally exposed. To be exposed in a museum means that the ladies, their words, will finally be looked at and read as a part of high culture, but to be exposed also means to be open to criticism, to be vulnerable. The Ladies' Gallery is also, literally, the name of a balcony in the chamber of the House of Representatives from where bullets where shot by a group of Puerto Rican nationalists in 1954, among whom was Lolita Lebrón, the grandmother of Vilar. This is the political crime for which she was convicted. It is from the ladies' gallery, understood as a female space, or "a room of ones own," that the world is seen in this book, since it is a woman, Vilar, who tells the lives of her grandmother, her mother, and herself. The room, or gallery, is also a room in a psychiatric hospital from where the act of writing begins.

The lives of these three women are implicitly contrasted with the location that is assigned to women in the national narratives. That detail, among others that I will proceed to explain, is what makes this a significant text. This is how the world is seen from the ladies' gallery at the beginning of the book:

MARCH 1, 1954. In the afternoon, a young woman together with three men entered the House of Representatives of the United States of America and opened fire. Next day, the front page of the New York Times would show the same woman wrapped on the revolutionary flag of Puerto Rico, her left fist raised high. What the Times would not quote were her words, "I did not come here to kill. I came here to die." (3)

The image of this woman wrapped on the Puerto Rican flag relies on a pervasive metaphor in political debates and cultural representations of the island's twentieth century: that silent image of a woman as nation. However, even though the words that Vilar puts on the lips of her grandmother rescue her from the silence of the simple visual image, to have her become a subject capable of naming herself; even if words are put in her mouth, the act of naming herself takes place in accordance with the nationalist narratives of self-sacrifice constructed by Puerto Rican male intellectuals in the latter part of the twentieth century, when she declares: "I did not come here to kill. I came here to die."

With her text, Vilar enters the Puerto Rican cultural field confronting a series of past assumptions that have given shape to debates about national identity 
and nationalism for over a hundred years now. The most obvious are her attacks on the image of women as nation, by the exposure of the straight-jackets it imposes on them: woman, it is assumed, can be the nation, and consequently the object for which men will perform their nation-saving deeds or actions: men will be the only agents, and the only citizens. ${ }^{8}$ But she not only criticizes the effects of this metaphor, she also challenges the elevation of self-sacrifice to the category of political strategy to obtain independence, as inscribed in the famous phrase by Pedro Albizu Campos, the leader of the Puerto Rican Nationalist Party: "The motherland is bravery and sacrifice" ("La patria es valor y sacrificio").

An equally important aspect of Vilar's text is the manner in which this manuscript circulated to become a published text. I suggest that the story that tells the journey of this text to publication has to be read along with the one that is told in the book, if we want to be able to unpack the multiplicity of political implications that are wrapped in it. We know that the book was published in English and not in Spanish, and this fact forces the reader from the island to wonder why it had to go through the work of a translator (Gregory Rabassa) to become a published work of literary art, since the implied reader seems to be the Spanish-speaking Puerto Rican who promoted the Hispanic cultural nationalism that claimed sacrifice as a political strategy. ${ }^{9}$ A reading that goes from the story told in the book to the one implied in the publication process is the most interesting to me, because English is the language that Puerto Rican intelligentsias on the island expelled from their canon, along with the Puerto Ricans who migrated to the U. S., who where also systematically expelled from the social imaginary. ${ }^{10}$ In spite of these attempts to erase them from the historical record, Puerto Ricans on the other side of the pond ("el charco") continued being Puerto Rican and the act of claiming a culture gave them the means to survive in the metropolises that received them. ${ }^{11}$ I am interested in the publication history of the book because I wonder if this book was expelled, as the migrant communities were, from the island's historical record by denying it the possibility of being published by local presses.

There are yet other issues this autobiography raises, among which the most interesting is an examination of the dialogue it establishes with other autobiographical texts constructed by Puerto Ricans who grew-up in the context of that migration, but experienced a totally different reality. Piri Thomas' work, Down These Mean Streets is an example of a text written by a Puerto Rican in the US that tells a different story: at least when considering race and class issues. Here the narrator is the son of a working class Puerto Rican family who starts his act of writing from prison, another enclosed space equivalent to the psychiatric hospital. The story he tells is different because he draws on a landscape other than the middle-class position and the privileged location in which Vilar lived in the US: a private secondary school and, later, the University of Rochester.

Encrucijada/Crossroads 1.1 (2003): 99-116 
Thomas challenges purist and monolithic Puerto Rican nationalism when writing in English, because it was the language he knew, and with this gesture his text helped to initiate a literature of the migration that has been expelled from the insular canon. ${ }^{12}$ By writing about the landscape of his experience, East Harlem or El Barrio, Thomas creates a symbolic economy in which he incorporates the social imaginary of both the U. S. and Puerto Rico.

Vilar, on the other hand, shows the effects of the symbolic economy that makes of the island a sick woman, to later promote the martyrdom of its male children. But to do this, her text has to be translated and published into English. The conditions that made this publication possible was opened many years ago when Thomas published his autobiography. In this manner, literature of the Diaspora comes full circle when it goes from being a marginal literature to being one with a well-established market - a market that enables the publication of texts that also talk about a Puerto Rican experience produced by an entirely different kind of migration.

\section{On Board and Flying}

The second wave of migration that is happening as I write was described in Puerto Rico by the media as the "brain drain," whose flow needed to be stemmed for the good of the island. This change of official position regarding migration is an extremely classist one, since when the people migrating were poor land workers nobody spoke about containing that particular flow of migration. Instead, it would be proposed to forget those migrated Puerto Ricans who would soon forsake their national identity and start becoming something else. "Brains" ("cerebros") was the name that the press used to describe the people with university or professional titles who were leaving to the U. S. in search of better salaries, or were escaping from the street violence of the island, and who had to be seduced to stay to promote and enlarge its industrial progress. Magali García Ramis wrote an essay parodying the media's representation of the new type of migrant, describing them as:

Cerebros; esa gran masa encefálica que como nube nuclear se desplaza lenta y constantemente hacia el extranjero; esos sesos con patitas que se suben a diario a los aviones rumbo a otra vida: doctores a Dallas, profesoras a Boston, maestros a Rutgers, pintores a San Francisco, trabajadores sociales a Nueva York, enfermeras a Chicago, arquitectos a Miami, investigadores a Washington ...(12)

Brains; that great encephalic mass that like a nuclear cloud moves slowly and constantly to foreign lands. Those pork brains with pigs feet that, like a giant cuchifrito, daily get on planes leaving for 
another life: doctors to Dallas, female professors to Boston, male teachers to Rutgers, painters to San Francisco, social workers to New York, nurses to Chicago, architects to Miami, researchers to Washington ... ${ }^{14}$

If it is classist to promote the erasure of the poor people who first left since the 1940s, and then attempt to keep on the island the professionals who leave after the 1980s, it is also problematic to arrive in the U.S. believing in the American Dream (because you need it if you are looking to fulfill it), and erase the professional class position that allows you to intervene in the US economy and public sphere with a greater degree of success than the generations before you. That is, precisely, the most problematic aspect in academic proposals made by successful professionals who have recently migrated to the US and found it easier to acquire economic and professional rewards. If on the island, crime, violence, along with bureaucracy and economic disadvantages, it is harder for these professionals to live a peaceful and rewarding life, we cannot forget several historic facts.

That same reality of violence is the product of the industrialization that created a consumer society without providing to a great sector of the population the income necessary to be able to consume. These individuals later organized an informal economy that allowed them to survive. ${ }^{15}$ At the same time, industrialization gave a significant sector of Puerto Rican society access to education, and therefore gave them or their parents (unless the class position was inherited) the professional status that allows them to succeed in the U.S. Together these facts demonstrate that what worked to the advantage of the "brains" that constitute the new migrant population of Puerto Ricans, worked also to create the violence and bureaucracy from which they escaped. It also worked to the disadvantage of the sectors who migrated with no professional titles and therefore had to fight to be incorporated successfully into U.S. economic and symbolic fields, at the same time that they had not much agency to perform the same struggle in the Puerto Rican cultural field. While the migrated "brains" can easily cash the capital (social, political, symbolic) accumulated by the struggle of the older generations of migrated Puerto Ricans, they should always remember how this capital they are cashing in was accumulated, and by whom.

One has to ask if Vilar's book could be read in this new context of migrations that have produced a very specific symbolic capital that now circulates in US media. ${ }^{16}$ But if the point of departure of Vilar's narrative is considered, then it becomes obvious that the answer is no: this book is not a complacent text about the pleasures of migrating or crossing borders. Her narrative starts in a lunatic asylum in the US, to later tell the story of a life divided between two borders: an infancy of political harassment in Puerto Rico, the death of a mother, and then a trip to experiencing adolescence in the US. In it, identity grows from

Encrucijada/Crossroads 1.1 (2003): 99-116 
migration, but the process she describes is so painful that she attempts suicide several times. Therefore, the image of Irene, the character represented in the book, does not correspond to the one described in the book review section of the New York Times: "Since her mother died, Ms. Vilar has lived as a peregrine, toting suitcases everywhere from Puerto Rico to Philadelphia, from Spain to New York" (3). ${ }^{17}$ It is for this reason that I interpret this book in dialogue with different audiences, the Puerto Rican on the island, the Puerto Rican in New York, and the mainstream American public that reads her book as a totally different work of art. Is the New York Times review of what seems to be a sort of jet-set traveling accurately describe the same experiences that Irene, the character in Vilar's text, had to live through? Is it the same experience of traveling that caused Piri's trouble at finding a community with which he could fully identify? In his book, the narrator/protagonist fought poverty, racial violence, and discrimination in the Puerto Rican community in New York and in other U.S. communities. His search leads him down a path of violence, crime, drug addiction, and, eventually, incarceration. By comparing Vilar's and Thomas' autobiographical texts, we see that after two generations, the writing produced by Puerto Ricans who have faced migration emerges from the enclosed spaces of the asylum and the prison. That, in a Foucauldian sense, brings to mind that migration is still both the result of violence and a violent act that forces the migrant soul to reconstruct itself.

For Vilar, distance enhances the quality of the dialogue with the island, allowing her to produce one of the most moving critiques of Puerto Rican nationalism. The cuts on her wrists, that are described by the New York Times writer as the only thing that sets Vilar apart from a normal gal, are set up in the textuality of the bibliography as the consequence of a search caused by a history of violence, that is usually denied in the island (Puerto Ricans are so peaceful, and welcoming, and humble, people say when describing on the streets the essence of a national spirit). So while in mainstream media the scars of this character are erased, I would rather concentrate on them, and explore what they mean for generations of Puerto Ricans that keep moving back and forth from continental U.S. to the island in the Caribbean. The violence that she deals with is a pervasive effect of a historical period. The days when Thomas lived and later shaped his memoir; and the ones that Lolita Lebrón, the grandmother, lived where marked by World War II, the War of Korea, massive migrations, social restructuring on the island, and political repression.

The violence implied in migration, that violence that made Piri live with an anger that he could not explain, and did not know how to manage, is suggested, even though not developed to explore its full implications, in an article published by the Puerto Rican historian Silvia Álvarez. She describes migration as a physical displacement in terms of Puerto Rican populism: 
La consolidación del populismo en Puerto Rico a partir de 1940 puede narrarse como una crónica de desplazamientos y de tráficos acelerados. Los umbrales provistos por dos guerras: la Segunda Guerra Mundial (1939-45) y la Guerra de Corea (1954), que involucraron traslados de contingentes numerosos de puertorriqueños; los amplios movimientos del campo a la ciudad debidos a los imperativos del desarrollismo industrial y al deslumbramiento ante las urbanizaciones; los exilios y encarcelamientos consubstanciales a la política de erradicación del nacionalismo y del independentismo; y los éxodos migratorios más intensos en nuestra historia constituyeron episodios simultáneos de desalojo, renovación, y reocupación de los espacios políticos, económicos, demográficos y culturales por el populismo puertorriqueño en una duración comprimida de 15 años. (92)

(The consolidation of populism in Puerto Rico, beginning in the 1940s can be told as a chronicle of movements and accelerated traffic. The limits were provided by two wars: World War II (1939-45), and the Korean War (1954). Those wars implied the movement of many Puerto Rican soldiers; [but also] the great movements of people from the country to the city due to the imperatives of industrial development policies; and the mesmerizing effect the construction of new suburban living had in peoples; the politic of eradication of the followers of the nationalist and independentist parties that implied the exile and imprisonment of their followers; and the most intense migration exodus of our history; all these constituted simultaneous scenes of eviction, renovation, and recuperation of political, economic, demographic, and cultural spaces provoked by populism in Puerto Rico in the short span of 15 years.)

The violence described here was physical, but there was also a symbolic violence perpetrated against women, homosexuals, and the migrant nationals. In the context of the colonial relationship with the US, the intellectual sector whose work was canonized in the 1940s portrayed women as the repository of the essence of cultural identity, which had to be, according to them, Hispanic and, therefore, male dominated, in opposition to matriarchal pattern, which they assumed was the organizing social structure of Anglo-Saxon cultures. ${ }^{18}$ According to this rhetoric, women could not become lettered intellectuals since the world of the letter was seen as a male territory. ${ }^{19}$ The production of culture by women had to be circumscribed to the oral domain and the security of the

Encrucijada/Crossroads 1.1 (2003): 99-116 
domestic private sphere. Otherwise women would have become masculinized and the world would have fallen from its natural order. ${ }^{20}$

Pedro Albizu Campos, the leader of the nationalist party, on the other hand, saw the motherland as a sick women that needed to be taken care of by her male sons, as Carlos Gil, a cultural critic from the island, has suggested. Since Gil's objective is to show that the role of the intellectual in the late-modern and post-nationalistic era should not be to take care of the mother-nation, he is not concerned with the context in which the Albizuist discourse was produced. Albizu's proposal of violence to the point of self-sacrifice was, as he continuously said, a desperate (if not practical) response to a violence being inflicted on the Puerto Rican people. A quick review of his speeches would make this fact evident. In them he accuses the US of performing experiments with radiation on Puerto Rican people, as well as promoting the use of contraceptives as a means of decimating the population. He also speaks of the testing of drugs (vaccines) on Puerto Rican people before they were approved for consumption in the U.S., the repression of the Nationalist Party, the Korean War and, perhaps the most delirious of his accusations, the deliberate infection of tuberculosis on the island through books as yet another means of decimating the population. Were these accusations the words of a madman? That is what many people taught. But, according to this, for Albizu, the motherland was not just a sick mother, it was a mother, yes, willfully sickened by a tyrant. For Albizu, also, if the male son of the motherland was not brave enough to save the sick mother, she would either force her misbehaving children to act in her defense, or be saved by her own heroic actions, as he explains:

El valor no necesita de la fuerza física. La mujer más endeble puede derribar un imperio si tiene valor. Que empuñen su rosario, que se inspiren en lo eterno. Y las mujeres nuestras serán las que empujarán los hombres a ser los hombres gloriosos para lo que han nacido. (151)

(Courage does not need of physical force. The weakest woman can overthrow an Empire if she has courage. Let them clutch their rosaries, let them draw inspiration from the eternal. And our women will be the ones that will push men to become the glorious men that they have been born to become.)

This description seems to embrace the same kind of resistance that women of Argentina used against the military dictatorship, and that has been analyzed by academic scholars as the new political tool of these, so called, post-political times: the use of the historical relegation of women to the sphere of the home, and motherhood, in the public sphere to claim rights when protesting in the public square in the name of their children, silently, as they have been taught to do. ${ }^{21}$ 
That is precisely the role that Lebrón assumed, to a much less effective political result, probably because she was alone.

Carlos Gil suggests that the time of the messianic intellectual is over, and that contemporary intelligentsia should go on a diet in order to loose intellectual weight: all the weight of the utopias that he had to produce. Free of these heavy weights the new intellectual of late modernity should concentrate on saving himself, goes the argument. ${ }^{22}$ In this context, I recall the words of Albizu not to say that he was right to call the people to start a revolution, even if it meant losing one's life. I just want to point out the effects of such a violent context. It made Albizu sound like a madman. Lolita Lebrón followed him, attempted to embody the nation, or the mother of the nation, or the woman that would inspire men to save the nation. In jail she became a mystic as her last resource to articulate some sort of resistance. ${ }^{23}$ The inheritor of this tradition, Vilar, does not find it so easy to go on a diet. The reason why I bring to memory the context of violence of the 1940s in Puerto Rico is not that I want to re-legitimize the Albizuist project. Rather, my intention is to question the complacent intellectuals who seem to see this neo-liberal stage of capitalism as the end of history. If diets make us feel so light, why is it that we are still dealing with the same issues of injustice, racism, discrimination, displacement, incarceration, and sickness?

\section{Landing}

Death and silence were a destiny that Vilar's grandmother had accepted when she confronted the US government with a Kamikaze attack, in response to Albizu's plea for brave sons and daughters. Death and silence were also assumed by her mother, who killed herself on March 1, 1977, "on the twenty-third anniversary of the attack on Congress" (Vilar 3), as a protest against her husband's infidelities. Again, the only way a woman could be a central part of a narrative, would be by killing herself, by being silent. The story of this book starts a little later, when the third woman of this family, confronted with this national myth of self-sacrifice, is placed in a lunatic asylum for attempting to kill herself. But, Vilar breaks the chain of martyrdom through the act of writing. "Mother has died, therefore I am. Not a nation, it is true, but a presence that remains. A book" (323). Thus Vilar's narrative becomes a book that closes a circle for her. Thomas, also, at the beginning of his narrative sets telling one's story as an instrument that will cure his suffering, or "make things better:" "He didn't give me a chance. Even before the first burning slap of his belt awakened tears of pain, I was still trying to get words out that would make everything right again" (4).

In both narratives, the writer, along with the implied readers, Puerto Ricans on both sides of the border, are healed of this past after the written talking cure. But what is the meaning of the refusal of Puerto Ricans on the island to read 
Vilar's book, if it is true, as I suspect, that it was not published in Spanish for the lack of publishers willing to make public such heavy words in such light times? I want to close this essay by remembering again that the publication of Piri Thomas' work is a condition of possibility for the publication of Vilar's work in English, by Pantheon and then Vintage. In the same manner, the work of the generation of the 1940s, along with the work done by the leaders of the Popular Democratic Party, and the Nationalist Party in Puerto Rico, with their displacements, use of force and absolutely modern debates with which they attempted to create a nation, all of them are conditions of possibility that created both an imaginary culture and a consumer society that allow contemporary academic intellectuals to suggest a lighter agenda for themselves. What Vilar's book suggests, among many other things, is that when there are so many heavy issues unresolved, we have to be careful about diets, because we run the risk of going up and down, like a yo-yo. 


\section{Notes}

${ }^{1}$ According to José Manuel Valenzüela: “Globalization processes or supranational formations of meaning refer to different processes of convergence and integration, and allude to codes, symbols, and information that circulated in a broad manner to most of the countries in the world. Notwithstanding, globalization also conveys processes of disintegration and the, sometimes violent, irruption in other fields of meaning." ("Los procesos de globalización o de formaciones de sentido supranacionales refieren a diferentes procesos de convergencia o de integración y aluden a códigos, símbolos e información que circulan de una manera amplia en la mayoría de los países del mundo. Sin embargo, la globalización también conlleva procesos de desintegración, de irrupción, a veces violenta en otras conformaciones de sentido" (216; all translations are my own).

${ }^{2}$ In the case of Mexico, migration is not necessarily the migration of people, but of the border itself. On top of that, the farm worker who goes to California does not operate in a land foreign to him, since he sees it as his own stolen property. Recognizing that fact, I do think that the process of migration was accelerated in the context of the modernization project of the 1940s in Mexico. In his most recent publication Néstor García Canclini says on this subject: "If it is true that this process started before what, in a strict sense, can be called globalization, is with these movements of the second half of the twentieth century that one arrives to the point in which, for example, a fifth of Mexicans and a fourth of Cubans live in the United States. Los Angeles turned into the third Mexican city, Miami into the second concentration of Cubans, and Buenos Aires the third Bolivian City." ("Si bien el proceso comenzó antes de lo que en rigor puede llamarse globalización, es con estos movimientos de la segunda mitad del siglo XX que se llega al punto en que, por ejemplo, una quinta parte de los mexicanos y una cuarta parte de los cubanos viven en los Estados Unidos. Los Ángeles se convirtió en la tercera ciudad mexicana, Miami la segunda concentración de cubanos, Buenos Aires la tercera urbe boliviana.") (Cited in Monsiváis 2). García Canclini argues that these stages of population movement cannot yet be called globalization. I argue that neo-liberalist practices that have created what we now call globalization were already operating when the industrialization projects of these two countries where conceived and implemented.

${ }^{3}$ The whole quote in Spanish reads: "Si el capitalismo expandía las industrias y sus relaciones sociales, y el imperialismo se caracterizó por la exportación de capital, el concepto de globalización se nos presenta como un concepto aparentemente aséptico que refiere a la mundialización de la subordicación a los países más poderosos (principalmente los Estados Unidos), así como a sus matrices de representaciones" (Valenzüela 217).

${ }^{4}$ In the second chapter of my Ph.D. dissertation I develop the symbolic parallels that the simultaneous industrializations in Mexico and Puerto Rico created. I have envisioned two chapters that will force the dialogue between Chicano and Nuyorican Literature with the ones produced on the respective mainlands. My project can be read within the context of the proposal in Borderless Borders. This book is the first one I've seen that creates a supranational frame for the comparative studies of the histories of the migrations to the United States and the relations of the mother countries of the migrant with the latter.

${ }^{5}$ I am thinking of Paz's El laberinto de la soledad, Antonio S. Pedreira's Insularismo, René Marqués' El puertorriqueño dócil, and many other essays that make an argument about cultural nationalism that expel the migrant national from the national cultural field.

\footnotetext{
${ }^{6}$ See, as examples, the works of Juan Flores and Gloria Anzaldúa.
}

Encrucijada/Crossroads 1.1 (2003): 99-116 


\begin{abstract}
${ }^{7}$ There is, as an Anglo example: the work of Emily Hicks. The context in which I am intervening more directly with this essay is probably formed by the publication of Puerto Rican Jam in the US, and in Puerto Rico, the work of some of the intellectuals that has been published in Polifonía Salvaje. On these anthologies I see a tendency to conceptualize the history of minorities in the US, on one hand, and the production of intellectual debate on the other, as easier and happier experiences and tasks than how they are experienced on daily life. In Puerto Rican Jam, for example, even though the writers are careful in signaling the inequality of the relationship of both, colonial countries and ethnic populations with the US, the final proposal on the introductory article to the anthology is jaibería, or the Puerto Rican refusal to play by the rules (similar to the famous "acato pero no cumplo" of colonial times) as the most valid political strategy for Puerto Ricans, both in the island and the US. The problem I see with this proposal is that if we conceive resistance politics as naturally happening in the daily life of peoples (which does happen), then we refuse to come up with a project that seems to be needed, or to criticize power structures. The most interesting essay in that anthology from my point of view is the one written by Agustín Lao, titled "Islands at the Crossroads." This essay ends with the following proposition: "Caribbean cosmopolitanism has since the nineteenth century included New York as one of the main stations of its metropolitan trajectories, but now with the "caribbeanization" and "Latinization" of the Big Apple, the continuous transit of Caribbean islanders has created a transinsular territory between the basin and the north continent. If the islands have always been at the crossroads of modernity, the 'postmodern island' now also 'repeats itself' in Manhattan, in Long Island, and in all the 'Calibanized' and 'insularized' embodiments of the global Caribbean diaspora. The archipelagos of Puerto Ricanness (our bodies, ourselves), in so far as they serve as intersection of the crossroads, could hopefully become midwifes for the birth of postcolonial imaginaries, and (ideally and paradoxically) gates of hopes for the gestation of postimperial worlds" (186). Caribbean peoples in the US should unite, yes. Also Caribbean peoples in their main islands, and Latinamericans too. But my attention on this article is focused on attempting to map a little of what happens to people when they migrate, as it is represented in the literature they write. This literature will contradict the representation of them in relation to confusion and lack, made from above, at the same time that it will talk about the painful experience of finding a space on this land, not letting go the abandoned land, and at the same time reconstructing the self. I am reading migrations within the context of violence that displacement generates. I find the success story problematic because it erases the history of violence against migrants in this country. The Ricky Martin story shows that whoever refuses to be whitewashed is violently excluded from the spaces in which hegemonic political, economic, and symbolic production occur: he does not and that explains his success. That is why I prefer to focus my attention on violence and its effects.

${ }^{8}$ See Elisabeth Dore for a study on how the Holy Family as a symbol of the ideal family has shaped family structures in Latin American societies. Mary Louise Pratt has a study in which she traces both the location of women in the literary imagination of modern Latin America and their dialogue with the literary canon to be able to create their own narratives. See "Women, Literature and National Brotherhood."

${ }^{9}$ A couple of years ago, while attending to a conference in California a friend and colleague, Lisa Sánchez González, who is Assistant Professor at the University of Texas (Austin), called my attention to this book and wondered why it apparently never came out in Spanish. This paper is a product of my conversations with her that day. The only way to confirm any publication information would be to talk to the author or the editor. I have made attempts to contact both and, up to this date, have not received an answer from any of them. This fact shaped my method of research here, which is to read implications from the information I have about the book and what I know about Puerto Rican cultural field.
\end{abstract}


${ }^{10}$ Here is how the historian Silvia Álvarez describes that: "After performing its role in the battle against unemployment and overpopulation, and after having crossed the border, the emigrant had to leave the stage of the narrative of modern Puerto Rico." ("Tras cumplir su rol en la batalla contra el desempleo y la sobrepoblación, y después de cruzar la frontera, el emigrante debía hacer mutis de la narrativa del Puerto Rico moderno. La salida era su ara sacrificial para la construcción del país; la entrada a los Estados Unidos marcaba la asingnación de un nuevo espacio, la adquisición de una nueva identidad conmesurable a la que dejaba atrás") (93).

${ }^{11}$ See the book Latino Cultural Citizenship for more detailed studies on the implications of claiming, precisely, cultural citizenship in the US.

${ }^{12}$ Flores locates Thomas' book as the precursor of the third stage of Puerto Rican literature in the United Stated. On that stage Puerto Ricans in the US write without dialoguing with the insular canon or with the tradition of writers that from New York dialogued with it. For a history of Puerto Rican writing in the US see "La literatura puertorriqueña en los Estados Unidos: Etapas y perspectivas."

${ }^{13}$ In an interview with Edgardo Rodríguez Juliá, that later came to be part of his chronicle Las tribulaciones de Jonás (1981) Luis Muñoz Marín, governor of the island during the industrialization period, declared about migration exactly what I paraphrase above, responding to a question about the politics of the Popular Democratic Party regarding migration. I quote his statement followed by Rodríguez Juliá's comment: “'We thought: after two generations there will no longer exist the problem of the Puerto Ricans in New York, simply because by then they will no longer be Puerto Rican [...]' My God, without sorrow or pain he just almost denied the Puerto Ricanness of Roberto... Roberto was saved by a hitch, by being of first generation... but his son... The energetic Puerto Ricanness of Roberto was the best proof that the sinister project of assimilation for emigrants had failed." ("'Nosotros pensamos: después de dos generaciones ya no existirá el problema de los puertorriqueños en Nueva York, sencillamente porque ya para entonces no serán puertorriqueños [...]' Dios mío, sin más, sin pena ni dolor, casi le ha negado la puertorriqueñidad a Roberto... Roberto se salvó por un pelo, por ser de primera generación... pero su hijo... La enérgica puertorriqueñidad de Roberto era la mejor prueba de que el siniestro proyecto de asimilación para los emigrantes había fracasado" (43).

${ }^{14}$ She also adds examples of people who leave to Mexico City and Saudi Arabia, but we all know that the bulk of our migrations go to American cities, named like that, with a single name, as if speaking of an endeared friend.

${ }^{15}$ Talking about Puerto Ricans in New York, this is how this fact is described in the introduction to Puerto Rican Jam: "The expulsion of Puerto Ricans from manufacturing jobs and the racist educational system that excluded Puerto Ricans from the best public schools produced a redundant labor force that could not reenter the formal labor market. This led to the formation of what some have called the Puerto Rican "underclass," which we prefer to call a displaced racialized/colonial population. Unable to find jobs, many Puerto Ricans developed survival strategies, legal or illegal, to overcome the crisis" (22). Another example in which drugs and violence are read in the context of world economy is given by an essay about Latin America and globalization, in which George Yúdice says: "My hypothesis about Latin America is not that informal economies or narco-traffic are postmodern phenomena, but that they represent alternative responses/proposals to the grand récit of postmodernity constructed by Lyotard, Jameson and people who wrote before them." ("Mi hipótesis en cuanto a Amperica Latina no rside en que las economías informales o el narcotráfico son fenómenos posmodernos, sino que representan respuestas/propuestas alternativas al grand récit de la posmodernidad construido por Lyotard, Jameson y sus predecesores" 68).

Encrucijada/Crossroads 1.1 (2003): 99-116 
${ }^{16}$ I recognize that the new "latino" imaginary that has imposed itself in US mass media has its New York born cultural icons, like Mark Anthony and Jennifer López. In fact, I think that their contributions to the mediatic imaginary are richer and more productive for the Latino and Puerto Rican communities than the image of the middle-class-island-born Ricky Martin (Ricardo Martínez).

${ }^{17}$ See Mirta Ojito.

${ }^{18}$ That is, of course the work of the writers that are now known as the Generation of the 1940s, and especially, René Marqués. To explain the canonization of the work of intellectuals that criticized the project of the populist sector, it has been said that while the populist (PPD) leaders got to rule in the political field, in the cultural field the independentist sectors were allowed to rule. For an intellectual history of those times in Puerto Rico see the first chapter of the title by Arlene Dávila.

${ }^{19}$ I discuss these symbolic displacements in Puerto Rican literature on the Second Chapter of my Doctoral Dissertation.

${ }^{20}$ For a brilliant article that explains how notions of masculinity and femininity are deployed in Puerto Rican lettered cultural debates see: Lugo Ortiz.

${ }^{21}$ I do agree with studies that see this as an important defensive strategy, even though I like to remember that it is that, a defensive strategy, which implies a specific (less empowered) position in a larger power structure. Two examples of articles that discuss the rupture of clear divisions between public and private sphere when women become politically engaged are Elizabeth Jelin, and Ann Matear.

${ }^{22}$ He says: "As normalized sons and daughters, not guilty ones, we know that it is not the health of our mother that we must take care of, but ours." ("Como hijos normalizados, no culpables, sabemos que no es la salud de la madre la que debemos cuidar, sino la nuestra") (135).

${ }^{23}$ In the first chapter of Jean Franco's study of women writing in Mexico she deals with mystical writing by women in colonial Mexico. About it she says: "The torment and obstacles the nuns relate reveal, however, that they were well aware of the danger of their words, since they constantly deny authorship. It was only by disappearing as authors and becoming mediums for the voice of God (or targets of the devil) that these women were able to speak of their experiences at all, though this did not always exempt them from the petty jealousies and entrapment in the web of intrigue that were intrinsic ingredients of convent life. More important, this self-effacement and their constant professions of obedience whenever they appeared to be trespassing on alien territory were the preconditions for their flights of the imagination. When they returned with messages from God or the Virgin, they still had to resort to considerable hedging before conveying the messages and 'secrets' so that their mystical knowledge should not be seen as undermining in any way the authority of the clergy" (15). 


\section{Works Cited}

Acosta Lespier, Ivonne. La palabra como delito: Los discursos por los que condenaron a Albizu Campos. Río Piedras: Editorial Cultural, 1993.

Álvarez Curbelo, Silvia. “Coartadas para la agresión: emigración, guerra, populismo." Rivera Nieves and Gil. 91-107.

Aparicio, Frances. Listening to Salsa. Hanover: Wesleyan University Press, 1998.

Bergmann, Emilie, et al. Women, Culture and Politics in Latin America: Seminar on Feminism and Culture in Latin America. Berkeley: University of California Press, 1990.

Bonilla, Frank, et al. Borderless Borders. Philadelphia: Temple University Press, 1998.

Dávila, Arlene. Sponsored Identities. Philadelphia: Temple University Press, 1997.

Dore, Elisabeth. "The Holy Family: Imagined Households in Latin American History." Gender Politics in Latin America. Ed. Elisabeth Dore. 101117.

---, ed. Gender Politics in Latin America. New York: Monthly Review Press, 1997.

Flores, Juan. La venganza de Cortijo. Río Piedras: Huracán, 1997.

Flores, William and Rina Benmayor. Latino Cutlrual Citizenship. Boston: Beacon Press, 1997.

Foucault, Michel. "The Discourse on Language." The Archaeology of Knowledge \& the Discourse on Language. New York: Pantheon Books, 1972.

Franco, Jean. Plotting Women. New York: Columbia University Press, 1989.

García Canclini, Néstor, ed. Culturas en globalización. América Latina-EuropaEstados Unidos: Libre comercio e integración. Venezüela: Nueva Sociedad, 1996.

---, ed. Cultura y pospolítica. México: Consejo Nacional para la Cultura y las Artes, 1991.

García Ramis, Magali. "Los celebros que se van y el corazón que se queda." $L a$ ciudad que me habita. Río Piedras: Huracán, 1993.

Gil, Carlos. "De la madre enferma albizuista a la cura de adelgazamiento tardomoderna." Rivera Nieves and Gil. 121-137.

Encrucijada/Crossroads 1.1 (2003): 99-116 
Hicks, D. Emily. Border Writing : The Multidimensional Text. Minneapolis: University of Minnesota Press, 1991.

Jelin, Elisabeth. "Engendering Human Rights." Dore. 65-83.

Lugo Ortiz, Agnes. "Nationalism, Male Anxiety, and the Lesbian Body in Puerto Rican Narrative." Molly and McKee Irwin. 76-100.

Marqués, René. "El puertorriqueño dócil.” El Puertorriqueño dócil y otros ensayos. Río Piedras: Cultural, 1993.

Matear, Ann. "Desde la protesta a la propuesta: The Institutionalization of the Women's Movement in Chile." Dore. 84-100.

Molloy, Sylvia and Robert McKee Irwin, eds. Hispanisms and Homosexualities. Durham and London: Duke University Press, 1998.

Monsiváis, Carlos. Rev. of La globalización imaginada, by Néstor García Canclini. La jornada semanal. 27 February 2000. http://serpiente.dgsca.una.mx/jornada/2000/feb00/000227/sem-libros.html.

Ojito, Mirta. "Shots That Hauted 3 Generations." The New York Times on the Web. . http://www.nytimes.com/library/books/052698puertorico-bookmemoir.html.

Paz, Octavio. El laberinto de la soledad. México: Fondo de Cultura Económica, 1994.

Pedreira, Antonio S. Insularismo. Río Piedras: Edil, 1973.

Pérez Ortiz, Melanie. "Entre cultura letrada, cultura popular y cultura de masas: El intelectual y la esfera pública en México y Puerto Rico. Una lectura de los textos de Carlos Monsiváis, Cristina Pacheco, Edgardo Rodríguez Juliá y Ana Lydia Vega." Diss. Stanford University, 1999.

Pratt, Mary Louise. "Women, Literature and National Brotherhood." Bergmann. 48-73.

Quintero, Ángel. Salsa, sabor y control. México: SXXI, 1998.

Rivera Nieves, Irma, and Carlos Gil, eds. Polifonía Salvaje. San Juan: Editorial Postdata, 1995.

Rodríguez Juliá, Edgardo. Las tribulaciones de Jonás. Río Piedras: Huracán, 1981.

Santos, Mayra. "Puerto Rican Underground." Journal of El Centro de Estudios Puertorriqueños. 1-2 (Spring 1996): 216-231.

Thomas, Piri. Down these Mean Streets. New York: Vintage, 1991.

Valenzüela Arce, José Manuel. "Etnia y nación en la frontera México-Estados Unidos." García Canclini, Culturas en globalización. 215-244.

Vilar, Irene. The Ladies' Gallery. New York: Vintage, 1998. 
Yúdice, George. "Posmodernidad y capitalismo transnacional en América Latina." García Canclini, Cultura y Pospolítica. 63-94. 